\title{
PENGUJIAN CISPR 32 PADA MOBILE PHONE CHARGER
}

\author{
CISPR 32 Testing on Mobile Phone Charger
}

\author{
Hadid Tunas Bangsawan dan Ika Prawesti Wulandari
}

Balai Riset dan Standardisasi Industri Surabaya, Jl. Jagir Wonokromo 360 Surabaya

E-mail: hadid-tb@kemenperin.go.id

\begin{abstract}
Abstrak
Pemerintah Republik Indonesia melalui Kementrian Komunikasi dan Informatika telah mengeluarkan Peraturan Direktur Jenderal Sumber Daya dan Perangkat Pos dan Informatika nomor 5 tahun 2019 tentang Persyaratan Teknis Alat dan/atau Perangkat Telekomunikasi Bergerak Seluler yang mewajibkan salah satunya untuk seluruh perangkat seluler yang beredar di Indonesia harus memenuhi persyaratan CISPR 32. Penelitian ini bertujuan untuk mengetahui gambaran awal sebaran charger perangkat seluler/ mobile phone charger yang memenuhi persyaratan pengujian CE sesuai CISPR 32 yang telah diwajibkan di Indonesia. Pengujian dilakukan berdasarkan standar CISPR 32 untuk conducted emmision (CE) terhadap ke 10 charger yang populer di pasaran. Pergantian hanya terjadi kepada kepala charger saja. Sebagai beban charger, digunakan sebuah mobile device dengan spesifikasi kapasitas baterai $4000 \mathrm{mAh}$. Dari hasil pengujian, dengan menerapkan nilai koreksi, didapat bahwa dari sepuluh charger yang diuji hanya terdapat empat charger yang memenuhi persyaratan pengujian CISPR 32.
\end{abstract}

Kata kunci: charger, CISPR 32, Conducted emission.

\begin{abstract}
Indonesian Goverment through Minstry of Communication and Informatics has been declare regulation Peraturan Direktur Jenderal Sumber Daya dan Perangkat Pos dan Informatika $5^{\text {th }}$ year 2019 about Persyaratan Teknis Alat dan/atau Perangkat Telekomunikasi Bergerak Seluler which is requires that all mobile devices in Indonesia must meet the requirements of CISPR 32. This study aims to determine the initial description of the distribution of mobile phone charger that meet the CE testing requirements according to CISPR 32 which has been a mandatory in Indonesia. The tests were carried out according to the CISPR 32 standard for conducting (CE) emissions against the 10 popular mobile phone chargers on the market. The replacement only happens to the charger head. As a charger's load, a mobile device with a battery capacity of $4000 \mathrm{mAh}$ is used. The results, with applying the correction value, it is found that only four of ten chargers tested that meet the requirements of the CISPR 32 tester.
\end{abstract}

Kata kunci: mobie phone charger, CISPR 32, Conducted emission.

\section{PENDAHULUAN}

Mobile phone charger adalah sebuah perangkat yang digunakan untuk mengisi daya sebuah mobile phone. Pada dasarnya mobile phone charger (charger) adalah power supply / adaptor dari tegangan AC jala-jala listrik yaitu 220 V $50 \mathrm{~Hz}$ menjadi tegangan DC untuk diisikan ke mobile phone. Karena dipergunakan untuk keperluan mobile/ bergerak maka dimensi dan berat merupakan hal yang utama dalam mendesain sebuah charger. Oleh karena itu dipilihlah power supply berjenis SMPS (Switching Mode Power Supply). Dibandingkan dengan power supply linier, SMPS memiliki kelebihan dalam bidang dimensi dan berat karena hanya membutuhkan trafo berukuran kecil. Namun kekurangan tipe SMPS adalah efek noise (Nicolae dkk, 2014) dan electromegnetic interference (EMI) lebih besar dari pada tipe linier.

Di sisi lain, Pemerintah Republik Indonesia melalui Kementrian Komunikasi dan Informatika telah mengeluarkan Peraturan Direktur Jenderal Sumber Daya dan Perangkat Pos dan Informatika nomor 5 tahun 2019 tentang Persyaratan Teknis 
Alat dan/atau Perangkat Telekomunikasi Bergerak Seluler yang mewajibkan salah satunya untuk seluruh perangkat seluler yang beredar di Indonesia harus memenuhi persyaratan CISPR 32. Salah satu parameter uji yang dipersyaratkan dalam CISPR 32 adalah uji Conducted emission. Penelitian ini bertujuan untuk mengetahui gambaran awal sebaran charger perangkat seluler / mobile phone charger yang memenuhi persyaratan pengujian CE sesuai CISPR 32 yang telah diwajibkan di Indonesia.

\section{TINJAUAN PUSTAKA}

Switched-Mode Power Supplies (SMPS) biasanya digunakan dalam sistem elektronik modern karena efisiensi konversi daya yang unggul serta ukuran dan berat transformator yang lebih kecil dibandingkan dengan catu daya linier. Terlepas dari kelebihannya, SMPS menghasilkan noise frekuensi tinggi yang menyebabkan masalah gangguan elektromagnetik (Bhargava dkk, 2011), (S. Wu dkk, 2010). Ada tiga mekanisme utama yang berkontribusi pada suara frekuensi tinggi (Wang dkk, 2015):

a) $(<30 \mathrm{MHz})$ harmonisa dari frekuensi switching;

b) (50-300 MHz) induktansi parasit dari loop switching;

c) (> $200 \mathrm{MHz}$ ) arus pemulihan balik di dioda tubuh FETs.

EMI ada dalam dua bentuk yaitu terkonduksi (conducted) dan terpancar (radiated). Emisi konduksi (conducted emission) mengacu pada kopling energi elektromagnetik yang dihasilkan oleh peralatan ke kabel dayanya (Jayasree, 2012). Interferensi yang dilakukan selanjutnya dapat diklasifikasikan menjadi dua jenis, yaitu common-mode dan differential-mode. Arus gangguan CM mengalir ke arah yang sama pada kedua konduktor daya dan kembali melalui konduktor arde dan dapat ditekan dengan menggunakan induktor dalam filter EMI yang ditempatkan secara seri dengan setiap saluran listrik dan oleh kapasitor yang dihubungkan dari kedua konduktor saluran listrik ke ground (Di Piazza dkk, 2009). Arus mode diferensial (DM) mengalir melalui satu konduktor ac dan kembali bersama yang lain (Heldwein dkk, 2004) dan dapat dikurangi oleh filter yang berisi induktor secara seri dan kapasitor yang dihubungkan secara paralel antara dua konduktor pembawa arus.

Setiap alat ukur untuk menjamin keakuratannya harus dilakukan kalibrasi secara berkala. Hasil dari kalibrasi adalah sertifikat hasil kalibrasi yang memuat diantaranya adalah hasil pengukuran, nilai ketidakpastian, dan nilai koreksi. Nilai koreksi adalah sebuah nilai yang harus ditambahakan pada hasil pengukuran untuk mendapatkan hasil yang sebenarnya. Hal ini dipengaruhi oleh kemampuan alat ukur masing-masing sehingga tidak dapat disamakan antara alat satu dengan yang lainnya (H\&D Fitzgerald, 2020).

\section{METODE PENELITIAN}

Pengujian dilakukan berdasarkan standar CISPR 32 untuk conducted emmision (CE) terhadap ke 10 charger. Charger didapat secara acak dari market place online di Indonesia dengan kriteria kepopuleran penjualan. Daftar charger dipaparkan pada Tabel 1. Tabel 1 memuat identifikasi dan arus output. Merek disamarkan karena penulis tidak dapat memverifikasi original brand dari charger tersebut sehingga digunakan identifikasi yang diberikan oleh penulis. Untuk penyederhanaan variabel maka dipilih sebuah HP dan sebuah kabel saja, pergantian hanya terjadi kepada kepala charger saja. Sebagai beban charger, digunakan sebuah mobile device dengan spesifikasi kapasitas baterai 4000 mAh.

Tabel 1 Contoh uji charger.

\begin{tabular}{lll}
\hline No. & Merek & Arus output \\
\hline 1 & Charger 1 & $1.5 \mathrm{~A}$ \\
2 & Charger 2 & $1.5 \mathrm{~A}$ \\
3 & Charger 3 & $2 \mathrm{~A}$ \\
4 & Charger 4 & $1 \mathrm{~A}$ \\
5 & Charger 5 & $1.5 \mathrm{~A}$ \\
6 & Charger 6 & $2 \mathrm{~A}$ \\
7 & Charger 7 & $1.55 \mathrm{~A}$ \\
8 & Charger 8 & $2 \mathrm{~A}$ \\
9 & Charger 9 & $1.5 \mathrm{~A}$ \\
10 & Charger 10 & $1.5 \mathrm{~A}$
\end{tabular}

Pengujian ini mengunakan fasilitas Laboratorium EMC di Balai Riset dan Standardisasi Industri Surabaya. Pengujian dilakukan di area ground plane dengan dimensi $2.0 \times 2.0 \times 2.0 \mathrm{~m}$ di dalam suatu shielded room. Benda uji yaitu charger diletakkan diatas sebuah meja non konduktif dengan dimensi meja tersebut $1.0 \times 1.5 \mathrm{~m}$ dengan ketinggian $0.8 \mathrm{~m}$ dari permukaan ground plane dan ditempatkan sedemikian hingga berjarak horisontal $0.4 \mathrm{~m}$ dari dinding ground plane. Kabel-kabel yang berpotensi menyentuh ground plane harus dijaga sedemikian hingga berjarak $5 \mathrm{~cm}$ dari ground 
plane. Charger disambungkan pada sumber daya yang disediakan oleh Line Impedance Stabilization Network (LISN). Karakteristik impedansi dan frekwensi LISN telah memenuhi standar yang diacu. Jalur L1 dan N dari LISN dimonitor nilai interferensi konduksinya oleh EMI test Receiver melalui kabel antarmuka tipe coaxial yang impedansi terminasinya bernilai 50 Ohm. Susunan konfigurasi pengujian ini digambarkan pada Gambar 1.

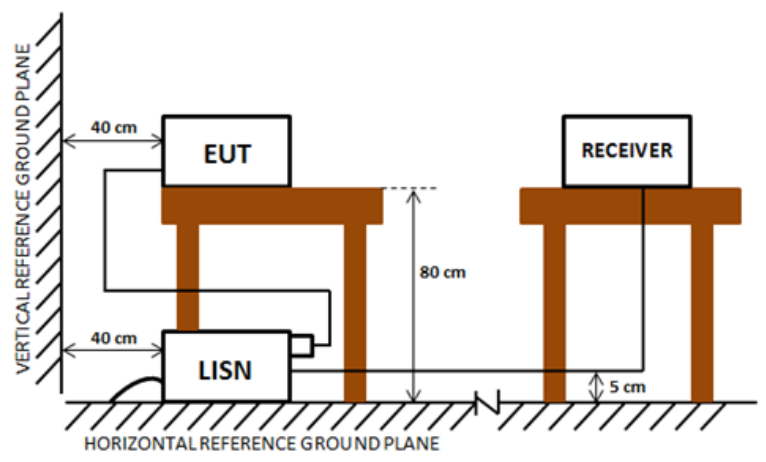

Gambar 1 Konfigurasi pengujian CE.

Sesuai dengan CISPR 32 klausa 5.1, Frekwensi pengukuran berada pada kisaran 150 $\mathrm{kHz}$ hingga $30 \mathrm{Mhz}$. Untuk masing-masing range frekwensi terdapat batas maksimal tingkatan quasi-peak dan average disebutkan pada tabel 2. Hasil pengukuran akan ditampilkan melalui software EMC32. Software setting EMC32 diatur sebagai berikut :

- $\quad$ Bandwidth penerima : $9 \mathrm{kHz}$

- Frequency step : $4 \mathrm{kHz}$

- Time step : $0.3 \mathrm{~s}$

Tabel 2 Batas pengujian

\begin{tabular}{ccc} 
Frequency & \multicolumn{2}{c}{ Limit $(\mathrm{dB} \mu \mathrm{V})$} \\
\cline { 2 - 3 } range $(\mathrm{MHz})$ & Quasi-peak & Average \\
\hline 0,15 ke 0,50 & 66 ke 56 & 56 ke 46 \\
0,50 ke 5 & 56 & 46 \\
5 ke 30 & 60 & 50
\end{tabular}

Catatan 1 Batas bawah berlaku pada frekuensi transisi

Catatan 2 Batas menurun secara linier dengan logaritmik frekuensi antara $0,15 \mathrm{MHz}$ untuk $0,50 \mathrm{MHz}$

Hasil dari pengukuran ke-10 charger yang ada kemudian akan dianalisis lebih lanjut. Analisis akan lebih ditekankan terhadap hasil uji yang tidak memenuhi persyaratan.

\section{HASIL DAN PEMBAHASAN}

Pengujian telah menerapkan konfigurasi yang dipersyaratkan oleh CISPR 32 seperti ditunjukkan pada Gambar 2.

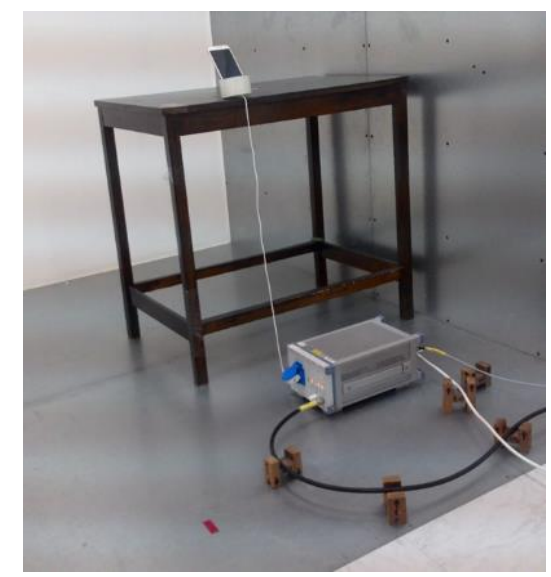

Gambar 2 Dokumentasi pengujian CE.

Hasil dari pengujian CE untuk charger 1 ditunjukkan pada grafik Gambar 3 dan Tabel 3. Pada grafik hasil pengujian tersebut, sumbu y merupakan level sinyal yang terekam dalam satuan desibel mikrovolt $(\mathrm{dB} \mu \mathrm{V})$ dan sumbu merupakan frekwensi dalam satuan hertz $(\mathrm{Hz})$. Garis merah dan ungu adalah batas-batas seperti tercantum dalam tabel 2, berturut-turut adalah batas quasi-peak dan average. Grafik warna biru dan hijau adalah hasil dari sinyal yang terekam untuk quasi-peak dan average. Titik-titik merah dan ungu adalah titik-titik tertinggi dari nilai quasipeak dan average yang menjadi perhatian. Selain itu, karena keterbatasan instrumen, terdapat nilai koreksi yang harus ditambahkan pada hasil untuk menghasilkan nilai yang sesungguhnya. Untuk pengukuran ini nilai koreksinya adalah $10 \mathrm{~dB}$. Nilai ini akan ditambahkan kepada nilai yang didapat saat pengujian sehingga didapat hasil yang sesungguhnya.

Dapat dilihat pada hasil pengujian CE untuk charger 1, semuanya dibawah limit quasipeak dan average yang dipersyaratkan oleh CISPR 32, namun ada 3 titik yang mempunyai margin kecil dari batas tersebut yaitu pada frekwensi $594 \mathrm{KHz}$ dan $608 \mathrm{Khz}$. Jika diaplikasikan koreksi terhadap hasil ini maka marginnya akan menjadi lebih besar. Dan disimpulkan bahwa charger 1 telah memenuhi standar pengujian $\mathrm{CE}$ sesuai CISPR 32. Untuk selanjutnya, hasil pengujian akan ditampilkan dalam bentuk tabel yang menunjukkan titik-titik tertinggi dari hasil yang didapat. Hasil pengujian CE untuk charger 2 sampai dengan 10 berurutan ditampilkan dalam Tabel 4 sampai dengan Tabel 12. 


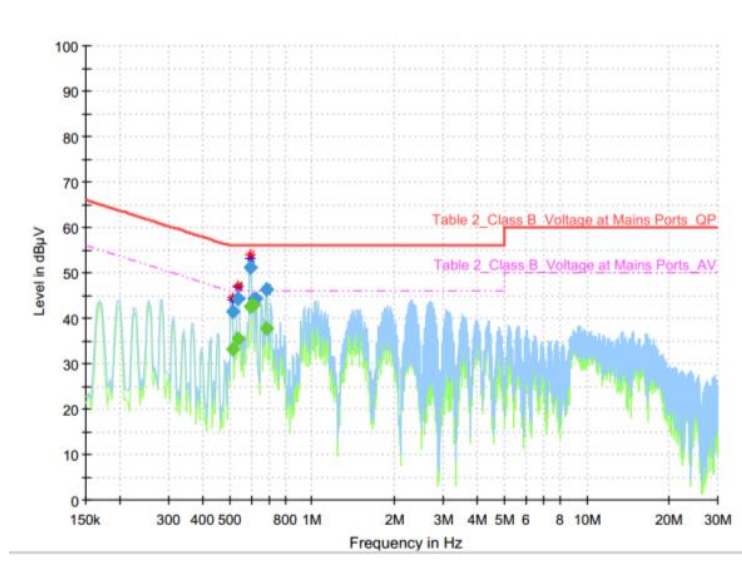

Gambar 3 Grafik hasil pengujian CE charger 1

Tabel 3 Tabel hasil pengujian CE charger 1

\begin{tabular}{lrrrr}
\hline $\begin{array}{l}\text { Frequency } \\
(\mathrm{MHz})\end{array}$ & $\begin{array}{l}\text { Quasi- } \\
\text { peak } \\
(\mathrm{dB} \mu \mathrm{V})\end{array}$ & $\begin{array}{l}\text { CAverage } \\
(\mathrm{dB} \mu \mathrm{V})\end{array}$ & $\begin{array}{l}\text { Limit } \\
(\mathrm{dB} \mu \mathrm{V})\end{array}$ & $\begin{array}{l}\text { Margin } \\
(\mathrm{dB})\end{array}$ \\
\hline 0.511931 & --- & 33.06 & 46.00 & 12.94 \\
0.511931 & 41.35 & --- & 56.00 & 14.65 \\
0.538050 & 44.32 & --- & 56.00 & 11.68 \\
0.538050 & --- & 35.31 & 46.00 & 10.69 \\
0.594019 & --- & 42.70 & 46.00 & 3.30 \\
0.594019 & 51.26 & --- & 56.00 & 4.74 \\
0.608944 & --- & 42.76 & 46.00 & 3.24 \\
0.623869 & 44.39 & --- & 56.00 & 11.61 \\
0.679838 & --- & 37.72 & 46.00 & 8.28 \\
0.679838 & 46.30 & --- & 56.00 & 9.70 \\
\hline
\end{tabular}

Hasil dari pengujian CE untuk charger 2 ditunjukkan pada grafik Tabel 4. Dari tabel tersebut terlihat bahwa hasil pengujian CE untuk charger 2 gagal pada beberapa titik yaitu pada frekwensi $388 \mathrm{KHz}, 519 \mathrm{Khz}$ untuk nilai quasi-peak dan average, serta pada frekwensi $582 \mathrm{KHz}$, $649 \mathrm{KHz}, 713 \mathrm{KHz}$ untuk nilai quasi-peak. Jika diaplikasikan nilai koreksi maka nilai yang melebihi ambang batas menjadi 2 saja yaitu nilai quasi-peak pada frekwensi $388 \mathrm{KH}$ dan $519 \mathrm{KHz}$. Dan disimpulkan bahwa charger 2 tidak memenuhi standar pengujian CE sesuai CISPR 32.
Tabel 4 Tabel hasil pengujian CE charger 2

\begin{tabular}{lrrrr}
\hline $\begin{array}{l}\text { Frequency } \\
(\mathrm{MHz})\end{array}$ & $\begin{array}{l}\text { Quasi- } \\
\text { peak } \\
(\mathrm{dB} \mu \mathrm{V})\end{array}$ & $\begin{array}{l}\text { CAverage } \\
(\mathrm{dB} \mu \mathrm{V})\end{array}$ & $\begin{array}{l}\text { Limit } \\
(\mathrm{dB} \mu \mathrm{V})\end{array}$ & $\begin{array}{l}\text { Margin } \\
(\mathrm{dB})\end{array}$ \\
\hline 0.388800 & --- & 49.24 & 48.09 & -1.15 \\
0.388800 & 69.27 & --- & 58.09 & -11.18 \\
0.519394 & --- & 46.19 & 46.00 & -0.19 \\
0.519394 & 66.90 & --- & 56.00 & -10.90 \\
0.582825 & --- & 44.59 & 46.00 & 1.41 \\
0.582825 & 64.54 & --- & 56.00 & -8.54 \\
0.649988 & --- & 43.45 & 46.00 & 2.55 \\
0.649988 & 62.64 & --- & 56.00 & -6.64 \\
0.713419 & 60.44 & --- & 56.00 & -4.44 \\
0.713419 & --- & 42.27 & 46.00 & 3.73 \\
\hline
\end{tabular}

Tabel 5 Tabel hasil pengujian CE charger 3

\begin{tabular}{lrrrr}
\hline $\begin{array}{l}\text { Frequency } \\
(\mathrm{MHz})\end{array}$ & $\begin{array}{l}\text { Quasi- } \\
\text { peak } \\
(\mathrm{dB} \mu \mathrm{V})\end{array}$ & $\begin{array}{l}\text { CAverage } \\
(\mathrm{dB} \mu \mathrm{V})\end{array}$ & $\begin{array}{l}\text { Limit } \\
(\mathrm{dB} \mu \mathrm{V})\end{array}$ & $\begin{array}{l}\text { Margin } \\
(\mathrm{dB})\end{array}$ \\
\hline 0.426112 & 72.31 & --- & 57.33 & -14.98 \\
0.426112 & --- & 53.89 & 47.33 & -6.56 \\
0.508200 & --- & 52.83 & 46.00 & -6.83 \\
0.508200 & 71.87 & --- & 56.00 & -15.87 \\
0.534319 & --- & 50.17 & 46.00 & -4.17 \\
0.534319 & 70.91 & --- & 56.00 & -14.91 \\
0.646256 & 67.24 & --- & 56.00 & -11.24 \\
0.646256 & --- & 48.08 & 46.00 & -2.08 \\
0.724612 & 65.40 & --- & 56.00 & -9.40 \\
0.728344 & --- & 52.12 & 46.00 & -6.12 \\
\hline
\end{tabular}

Hasil dari pengujian CE untuk charger 3 ditunjukkan pada grafik Tabel 5. Dari tabel tersebut terlihat bahwa hasil pengujian CE untuk charger 3 gagal pada 5 titik frekwensi baik pada nilai quasi-peak maupun average yaitu pada frekwensi $426 \mathrm{KHz}, 508 \mathrm{Khz}, 534 \mathrm{KHz}, 646 \mathrm{KHz}$, $724 \mathrm{KHz}$. Jika diaplikasikan nilai koreksi maka nilai yang melebihi ambang batas adalah nilai quasipeak pada frekwensi $426 \mathrm{KHz}, 508 \mathrm{Khz}, 534 \mathrm{KHz}$, $646 \mathrm{KHz}$, sehingga disimpulkan bahwa charger 3 tidak memenuhi standar pengujian CE sesuai CISPR 32. 
Pengujian Cispr 32 pada Mobile Phone Charger Hadid Tunas Bangsawan dan Ika Prawesti Wulandari

Tabel 6 Tabel hasil pengujian CE charger 4

\begin{tabular}{lrrrr}
\hline $\begin{array}{l}\text { Frequency } \\
(\mathrm{MHz})\end{array}$ & $\begin{array}{l}\text { Quasi- } \\
\text { peak } \\
(\mathrm{dB} \mu \mathrm{V})\end{array}$ & $\begin{array}{l}\text { CAverage } \\
(\mathrm{dB} \mu \mathrm{V})\end{array}$ & $\begin{array}{l}\text { Limit } \\
(\mathrm{dB} \mu \mathrm{V})\end{array}$ & $\begin{array}{l}\text { Margin } \\
(\mathrm{dB})\end{array}$ \\
\hline 0.586556 & --- & 48.90 & 46.00 & -2.90 \\
0.586556 & 63.48 & --- & 56.00 & -7.48 \\
1.306688 & --- & 45.46 & 46.00 & 0.54 \\
1.896225 & --- & 42.45 & 46.00 & 3.55 \\
1.896225 & 57.86 & --- & 56.00 & -1.86 \\
2.000700 & 54.11 & --- & 56.00 & 1.89 \\
2.000700 & --- & 41.54 & 46.00 & 4.46 \\
2.239500 & 46.36 & --- & 56.00 & 9.64 \\
2.239500 & --- & 35.11 & 46.00 & 10.89 \\
4.418550 & 41.43 & --- & 56.00 & 14.57 \\
\hline & & & &
\end{tabular}

Hasil dari pengujian CE untuk charger 4 ditunjukkan pada grafik Tabel 6. Dari tabel tersebut terlihat bahwa hasil pengujian CE untuk charger 4 gagal pada 2 titik frekwensi saja yaitu frekwensi $586 \mathrm{KHz}$ baik pada nilai quasi-peak maupun average dan frekwensi $1,426 \mathrm{KHz}$ untuk nilai quasi-peaknya. Jika diaplikasikan koreksi maka keseluruhan nilai berada di bawah ambang batasnya sehingga disimpulkan bahwa charger 4 telah memenuhi standar pengujian CE sesuai CISPR 32.

Tabel 7 Tabel hasil pengujian CE charger 5

\begin{tabular}{lrrrr}
\hline $\begin{array}{l}\text { Frequency } \\
(\mathrm{MHz})\end{array}$ & $\begin{array}{l}\text { Quasi- } \\
\text { peak } \\
(\mathrm{dB} \mu \mathrm{V})\end{array}$ & $\begin{array}{l}\text { CAverage } \\
(\mathrm{dB} \mu \mathrm{V})\end{array}$ & $\begin{array}{l}\text { Limit } \\
(\mathrm{dB} \mu \mathrm{V})\end{array}$ & $\begin{array}{l}\text { Margin } \\
(\mathrm{dB})\end{array}$ \\
\hline 0.724612 & 54.01 & --- & 56.00 & 1.99 \\
0.724612 & -- & 46.58 & 46.00 & -0.58 \\
0.799238 & 51.90 & --- & 56.00 & 4.10 \\
0.799238 & --- & 45.90 & 46.00 & 0.10 \\
0.967144 & --- & 37.64 & 46.00 & 8.36 \\
0.967144 & 46.17 & --- & 56.00 & 9.83 \\
1.448475 & --- & 41.00 & 46.00 & 5.00 \\
1.448475 & 49.86 & --- & 56.00 & 6.14 \\
1.526831 & --- & 39.45 & 46.00 & 6.55 \\
1.526831 & 46.99 & --- & 56.00 & 9.01 \\
\hline
\end{tabular}

Hasil dari pengujian CE untuk charger 5 ditunjukkan pada grafik Tabel 7. Dari tabel tersebut terlihat bahwa hasil pengujian CE untuk charger 5 gagal pada 1 titik frekwensi saja yaitu nilai average pada frekwensi $724 \mathrm{KHz}$. Jika diaplikasikan koreksi maka keseluruhan nilai berada di bawah ambang batasnya sehingga disimpulkan bahwa charger 5 telah memenuhi standar pengujian CE sesuai CISPR 32.
Tabel 8 Tabel hasil pengujian CE charger 6

\begin{tabular}{lrrrr}
\hline $\begin{array}{l}\text { Frequency } \\
(\mathrm{MHz})\end{array}$ & $\begin{array}{l}\text { Quasi- } \\
\text { peak } \\
(\mathrm{dB} \mu \mathrm{V})\end{array}$ & $\begin{array}{l}\text { CAverage } \\
(\mathrm{dB} \mu \mathrm{V})\end{array}$ & $\begin{array}{l}\text { Limit } \\
(\mathrm{dB} \mu \mathrm{V})\end{array}$ & $\begin{array}{l}\text { Margin } \\
(\mathrm{dB})\end{array}$ \\
\hline 0.295519 & --- & 50.75 & 50.37 & -0.38 \\
0.295519 & 80.69 & --- & 60.37 & -20.32 \\
0.351488 & --- & 42.82 & 48.93 & 6.11 \\
0.351488 & 75.94 & --- & 58.93 & -17.01 \\
0.411188 & 72.27 & --- & 57.62 & -14.65 \\
0.411188 & --- & 41.84 & 47.62 & 5.78 \\
0.467156 & 64.03 & --- & 56.56 & -7.47 \\
0.467156 & --- & 40.69 & 46.56 & 5.87 \\
0.526856 & --- & 42.69 & 46.00 & 3.31 \\
0.526856 & 62.11 & --- & 56.00 & -6.11 \\
\hline
\end{tabular}

Hasil dari pengujian CE untuk charger 6 ditunjukkan pada grafik Tabel 8. Dari tabel tersebut terlihat bahwa hasil pengujian CE untuk charger 6 gagal pada 6 titik yaitu nilai quasi-peak dan average pada frekwensi $295 \mathrm{KHz}$ dan nilai quasi-peak pada frekwensi $351 \mathrm{KHz}, 411 \mathrm{KHz}$, $467 \mathrm{KHz}, 526 \mathrm{KHz}$. Jika diaplikasikan koreksi maka nilai berada di atas ambang batasnya adalah nilai quasi-peak pada frekwensi $295 \mathrm{KHz}$, $351 \mathrm{KHz}, 411 \mathrm{KHz}$. Sehingga disimpulkan bahwa charger 6 tidak memenuhi standar pengujian $\mathrm{CE}$ sesuai CISPR 32.

Tabel 9 Tabel hasil pengujian CE charger 7

\begin{tabular}{lrrrr}
\hline $\begin{array}{l}\text { Frequency } \\
(\mathrm{MHz})\end{array}$ & $\begin{array}{l}\text { Quasi- } \\
\text { peak } \\
(\mathrm{dB} \mu \mathrm{V})\end{array}$ & $\begin{array}{l}\text { CAverage } \\
(\mathrm{dB} \mu \mathrm{V})\end{array}$ & $\begin{array}{l}\text { Limit } \\
(\mathrm{dB} \mu \mathrm{V})\end{array}$ & $\begin{array}{l}\text { Margin } \\
(\mathrm{dB})\end{array}$ \\
\hline 0.541781 & --- & 28.21 & 46.00 & 17.79 \\
0.541781 & 37.00 & --- & 56.00 & 19.00 \\
1.541756 & --- & 28.46 & 46.00 & 17.54 \\
3.287981 & --- & 29.70 & 46.00 & 16.30 \\
3.287981 & 37.35 & -- & 56.00 & 18.65 \\
3.396188 & 37.87 & -- & 56.00 & 18.13 \\
3.422306 & 37.57 & -- & 56.00 & 18.43 \\
3.422306 & --- & 29.72 & 46.00 & 16.28 \\
3.444694 & --- & 29.60 & 46.00 & 16.40 \\
3.444694 & 37.28 & --- & 56.00 & 18.72 \\
\hline
\end{tabular}

Hasil dari pengujian CE untuk charger 7 ditunjukkan pada grafik Tabel 9. Tidak terdapat nilai yang melebihi ambang batas. Dan jika diaplikasikan koreksi maka nilai tersebut akan menjadi lebih baik. Sehingga disimpulkan bahwa charger 7 telah memenuhi standar pengujian CE sesuai CISPR 32. 
Tabel 10 Tabel hasil pengujian CE charger 8

\begin{tabular}{lrrrr}
\hline $\begin{array}{l}\text { Frequency } \\
(\mathrm{MHz})\end{array}$ & $\begin{array}{l}\text { Quasi- } \\
\text { peak } \\
(\mathrm{dB} \mu \mathrm{V})\end{array}$ & $\begin{array}{l}\text { CAverage } \\
(\mathrm{dB} \mu \mathrm{V})\end{array}$ & $\begin{array}{l}\text { Limit } \\
(\mathrm{dB} \mu \mathrm{V})\end{array}$ & $\begin{array}{l}\text { Margin } \\
(\mathrm{dB})\end{array}$ \\
\hline 0.485812 & --- & 57.39 & 46.24 & -11.15 \\
0.485812 & 79.48 & --- & 56.24 & -23.24 \\
0.549244 & --- & 54.88 & 46.00 & -8.88 \\
0.549244 & 77.95 & --- & 56.00 & -21.95 \\
1.217138 & 69.53 & --- & 56.00 & -13.53 \\
1.217138 & --- & 48.62 & 46.00 & -2.62 \\
1.280569 & 69.38 & --- & 56.00 & -13.38 \\
1.280569 & --- & 49.37 & 46.00 & -3.37 \\
1.340269 & --- & 49.55 & 46.00 & -3.55 \\
1.340269 & 68.95 & --- & 56.00 & -12.95 \\
\hline
\end{tabular}

Hasil dari pengujian CE untuk charger 8 ditunjukkan pada grafik Tabel 10. Dari tabel tersebut terlihat bahwa hasil pengujian CE untuk charger 8 gagal pada 10 titik yaitu nilai quasi-peak dan average pada frekwensi $485 \mathrm{KHz}, 549 \mathrm{KHz}$, $1,217 \mathrm{KHz}, 1,280 \mathrm{KHz}, 1,340 \mathrm{KHz}$. Jika diaplikasikan koreksi maka nilai yang berada di atas ambang batasnya adalah nilai quasi-peak pada frekwensi $485 \mathrm{KHz}, 549 \mathrm{KHz}, 1,217 \mathrm{KHz}$, $1,280 \mathrm{KHz}, 1,340 \mathrm{KHz}$ dan nilai average pada frekwensi $485 \mathrm{KHz}$. Sehingga disimpulkan bahwa charger 8 tidak memenuhi standar pengujian CE sesuai CISPR 32.

Tabel 11 Tabel hasil pengujian CE charger 9

\begin{tabular}{lrrrr}
\hline $\begin{array}{l}\text { Frequency } \\
(\mathrm{MHz})\end{array}$ & $\begin{array}{l}\text { Quasi- } \\
\text { peak } \\
(\mathrm{dB} \mu \mathrm{V})\end{array}$ & $\begin{array}{l}\text { CAverage } \\
(\mathrm{dB} \mu \mathrm{V})\end{array}$ & $\begin{array}{l}\text { Limit } \\
(\mathrm{dB} \mu \mathrm{V})\end{array}$ & $\begin{array}{l}\text { Margin } \\
(\mathrm{dB})\end{array}$ \\
\hline 1.034306 & 37.61 & --- & 56.00 & 18.39 \\
1.034306 & -- & 8.98 & 46.00 & 37.02 \\
1.773094 & 29.56 & --- & 56.00 & 26.44 \\
1.773094 & --- & 10.43 & 46.00 & 35.57 \\
2.366362 & --- & 20.83 & 46.00 & 25.17 \\
2.366362 & 38.26 & --- & 56.00 & 17.74 \\
2.511881 & 34.64 & -- & 56.00 & 21.36 \\
2.511881 & -- & 51.02 & 46.00 & -5.02 \\
3.105150 & 67.63 & -- & 56.00 & -11.63 \\
3.105150 & --- & 9.74 & 46.00 & 36.26 \\
\hline
\end{tabular}

Hasil dari pengujian CE untuk charger 9 ditunjukkan pada grafik Tabel 11. Dari tabel tersebut terlihat bahwa hasil pengujian CE untuk charger 9 gagal pada 2 titik frekwensi yaitu nilai average pada frekwensi $2,511 \mathrm{KHz}$ dan nilai quasi-peak pada frekwensi $3,105 \mathrm{KHz}$. Jika diaplikasikan koreksi maka keseluruhan nilai yang melebihi ambang batas adalah nilai quasi-peak pada frekwensi $3,105 \mathrm{KHz}$. Sehingga disimpulkan bahwa charger 9 tidak memenuhi standar pengujian CE sesuai CISPR 32.

Tabel 12 Tabel hasil pengujian CE charger 10

\begin{tabular}{lrrrr}
\hline $\begin{array}{l}\text { Frequency } \\
(\mathrm{MHz})\end{array}$ & $\begin{array}{l}\text { Quasi- } \\
\text { peak } \\
(\mathrm{dB} \mu \mathrm{V})\end{array}$ & $\begin{array}{l}\text { CAverage } \\
(\mathrm{dB} \mu \mathrm{V})\end{array}$ & $\begin{array}{l}\text { Limit } \\
(\mathrm{dB} \mu \mathrm{V})\end{array}$ & $\begin{array}{l}\text { Margin } \\
(\mathrm{dB})\end{array}$ \\
\hline 0.179850 & --- & 77.06 & 54.49 & -22.57 \\
0.179850 & 91.97 & --- & 64.49 & -27.48 \\
0.239550 & --- & 73.85 & 52.11 & -21.74 \\
0.239550 & 88.75 & --- & 62.11 & -26.64 \\
0.302981 & 86.18 & --- & 60.16 & -26.02 \\
0.302981 & --- & 69.90 & 50.16 & -19.74 \\
0.362681 & --- & 66.16 & 48.67 & -17.49 \\
0.366412 & 83.03 & --- & 58.58 & -24.45 \\
0.422381 & --- & 62.95 & 47.40 & -15.55 \\
0.422381 & 79.51 & --- & 57.40 & -22.11 \\
\hline
\end{tabular}

Hasil dari pengujian CE untuk charger 10 ditunjukkan pada grafik Tabel 12. Dari tabel tersebut terlihat bahwa hasil pengujian CE untuk charger 10 gagal pada 10 titik yaitu nilai quasipeak dan average pada frekwensi $179 \mathrm{KHz}, 239$ $\mathrm{KHz}, 302 \mathrm{KHz}, 422 \mathrm{KHz}$, dan nilai average pada frekwensi $362 \mathrm{KHz}$ serta nilai quasi-peak pada frekwensi $366 \mathrm{KHz}$. Jika diaplikasikan koreksi maka nilai-nilai tersebut masih berada di atas ambang batasnya. Sehingga disimpulkan bahwa charger 10 tidak memenuhi standar pengujian CE sesuai CISPR 32.

\section{KESIMPULAN}

Dari hasil pengujian sepuluh charger yang ada, hanya terdapat empat buah charger saja yang memenuhi persyaratan pengujian CE sesuai CISPR 32. Hal ini menunjukkan bahwa masih sangat lemah penerapan perdirjen SDPPI no 5 tahun 2019 tersebut. Sebaiknya dilakukan penelitian lanjutan dengan sampel yang lebih beragam sehingga dapat diketahui sebaran charger yang memenuhi persyaratan CISPR 32 yang lebih akurat.

\section{UCAPAN TERIMAKASIH}

Penulis ingin mengucapkan terimakasih kepada Balai Riset dan Standardisasi Industri Surabaya atas dana dan kesempatan yang diberikan untuk menggunakan fasilitas Laboratorium EMC. 


\section{DAFTAR PUSTAKA}

Nicolae, P. M., Stoica, C. M., \& Mihai, G. (2014, October). Conducted emission measurements for a laptop. In 2014 International Conference on Applied and Theoretical Electricity (ICATE) (pp. 1-4). IEEE.

Bhargava, A.; Pommerenke, D.; Kam, K.W.; Centola, F.; Cheng Wei Lam, "DC-DC Buck Converter EMI Reduction Using PCB Layout Modification," Electromagnetic Compatibility, IEEE Transactions on, vol.53, no.3, pp.806,813, Aug. 2011.

S. Wu; K. Kam; D. Pommerenke; B. Cornelius; H. Shi; M. Herndon; J. Fan, "Investigation of noise coupling from switching power supply to signal nets," Electromagnetic Compatibility (EMC), 2010 IEEE International Symposium on, vol., no., pp.79,84, 25-30 July 2010.

Wang, Y., Bai, S., Guo, X., Jin, S., Zhang, Y., Eriksson, J., ... \& Fan, J. (2015, March). Conducted-emission modeling for a switched-mode power supply (SMPS). In 2015 IEEE Symposium on Electromagnetic Compatibility and Signal Integrity (pp. 314319). IEEE.

Jayasree, P. V. Y., Priya, J. C., Poojita, G. R., \& Kameshwari, G. (2012). EMl filter design for reducing common-mode and differential-mode noise in conducted interference. EMI Filter Design for Reducing Common-Mode and DifferentialMode Noise in Conducted Interference.

Di Piazza, M. C., Ragusa, A., \& Vitale, G. (2009). Design of grid-side electromagnetic interference filters in $\mathrm{AC}$ motor drives with motor-side common mode active compensation. IEEE Transactions on Electromagnetic Compatibility, 51(3), 673682.

Heldwein, M. L., Nussbaumer, T., \& Kolar, J. W. (2004, June). Differential mode EMC input filter design for three-phase AC-DC-AC sparse matrix PWM converters. In 2004 IEEE 35th Annual Power Electronics Specialists Conference (IEEE Cat. No. 04CH37551) (Vol. 1, pp. 284-291). IEEE.

H\&D Fitzgerald, Papers, Using \& Understanding a Calibration Certificate(2020). Diakses pada Juli 2020 dari https://www.density.co.uk/papers/usingunderstanding-a-calibrationcertificate\#: :text=The\%20calibration\%20c ertificate $\% 20$ tells $\% 20$ us,points $\% 20$ across \%20the\%20instrument's\%20range.

I.P. Wulandari, A.Y. Wirapraja, N. S. Bahari(2016). Pengukuran dan analisa karakteristik emisi elektromagnetik beberapa jenis power adapter pada mobile devices.

Jiraprasertwong, J., \& Jettanasen, C. (2015). Practical Design of a Passive EMI Filter for Reduction of EMI Generation. In Proceedings of the International MultiConference of Engineers and Computer Scientists 2015 (Vol. II, pp. 1821)

Shih, F., Chen, D. Y., Member, S., Wu, Y., \& Chen, Y. (1996). A Procedure for Designing EMI Filters for AC Line Applications. IEEE TRANSACTIONS ON POWER ELECTRONICS, 11(1). 
